\title{
Learning in Virtual Teams: Exploring the Student Experience
}

\author{
Annegret Goold, Naomi Augar and James Farmer \\ Deakin University, Australia
}

\author{
agoold@deakin.edu.au augar@deakin.edu.au \\ jfarmer@deakin.edu.au
}

\begin{abstract}
In 2005 an undergraduate course in project management was converted from face-to-face mode to wholly online mode. The online course was designed with an underlying problem-based learning (PBL) pedagogy and used a simulated, fictitious telecommunications company, United Enterprises (UE), as a case study learning resource. The students worked in virtual teams to complete online learning activities and to solve authentic project management tasks for UE.

This paper reports the findings of three surveys that were completed by students during the semester, to gauge their opinions about their experiences of working in virtual teams within the learning environment. Most students indicated that they valued the opportunity to discuss various aspects of the course with peers and faculty online, and to interact with real-life employees of UE. Overall the findings show that students were satisfied with this style of learning and enjoyed the experience of working collaboratively within a virtual team.
\end{abstract}

Keywords: Virtual Teams, E-Learning, Drupal, Problem-based Learning.

\section{Biographies}

Annegret Goold is a lecturer in the School of Engineering and Information Technology at Deakin University, Australia. Prior to joining Deakin in 1993 she worked as a computer programmer, analyst, technical writer and trainer. At present she teaches introductory IT, software engineering, project management and IT practice. Her research interests align with her teaching areas as well as in computer science education - particularly in online teaching and learning.

Naomi Augar completed her Bachelor of Computing (Applied Computing) with Honours in 2002 at Deakin University, Australia. Presently she is a PhD candidate in the School of Engineering and Information Technology at Deakin. Her PhD topic is "Supporting community, culture and collaboration with emerging e-Learning technologies." Her research interests include issues relating to constructing an online identity, virtual communication and e-learning. She has had exten-

Material published as part of this publication, either on-line or in print, is copyrighted by the Informing Science Institute. Permission to make digital or paper copy of part or all of these works for personal or classroom use is granted without fee provided that the copies are not made or distributed for profit or commercial advantage AND that copies 1) bear this notice in full and 2) give the full citation on the first page. It is permissible to abstract these works so long as credit is given. To copy in all other cases or to republish or to post on a server or to redistribute to lists requires specific permission and payment of a fee. Contact Publisher@InformingScience.org to request redistribution permission. sive teaching experience both in face-toface classes and in teaching online.

James Farmer is a Lecturer in Academic Development, Education Design and Research at Deakin University. He runs incsub.org. He is particularly interested in the use of social software in education, community and society. 